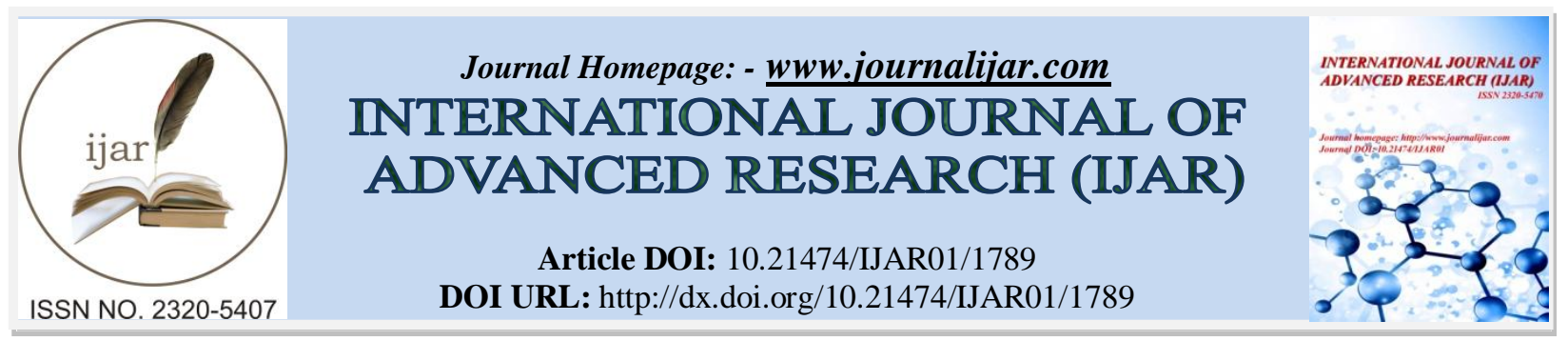

RESEARCH ARTICLE

\title{
ATTENTION DEFICIT HYPERACTIVITY DISORDER: AN IGNORED DISORDER IN PRIMARY SCHOOL CHILDREN IN ARAR, NORTHERN SAUDI ARABIA.
}

\section{Nagah Mohamed Aboel-Fetoh ${ }^{1}$, Jamilah Faisal Alnathir ${ }^{2}$, Aminah Abdullah Alhussain ${ }^{2}$ and Hayat Faisal Alnathir'.}

1. Assistant professor of Public Health and Community Medicine Department, Faculty of Medicine, Sohag University, Sohag, Egypt and Faculty of Medicine, Northern border University, Arar, KSA.

2. $6^{\text {th }}$ year students, Faculty of Medicine, Northern border University, Arar, KSA.

3. $3^{\text {rd }}$ year students, Faculty of Medicine, Northern border University, Arar, KSA.

\section{Manuscript Info}

Manuscript History

Received: 12 August 2016

Final Accepted: 22 September 2016

Published: October 2016

\section{Abstract}

Background:- Attention deficit hyperactivity disorder (ADHD) is a neglected illness in Arar, Norther area, Kingdom of Saudi Arabia. Objective:- The objective of this study is to determine the prevalence of ADHD among primary schools children of Arar city, the capital of the Northern province of the Kingdom of Saudi Arabia.

Methods:- A structured self-administered questionnaire was used to collect information from the teachers of children who attended 4 randomly selected primary schools in Arar city during the study period. The Conners 10-item Abbreviated Teacher Rating Scale (ATRS) was used.

Results:- 85 children fulfilled the stated criteria for ADHD giving a prevalence rate of $27.9 \%$.

Conclusion:- The prevalence of ADHD in our setting is 27.9\%, which is more than that obtained elsewhere in the world.

Copy Right, IJAR, 2016,. All rights reserved.

\section{Introduction:-}

Attention deficit hyperactivity disorder (ADHD) is defined by features of inattention, over activity, and impulsivity. It is the most frequently encountered childhood-onset neurodevelopmental disorder in the primary care settings [1].

ADHD normally affects preschool age children, although it can extend beyond childhood and adolescence into adulthood and a higher prevalence is often reported in males [2].

Publication of the American Academy of Pediatrics (AAP) guidelines for assessment [3] and management [4] of attention-deficit/hyperactivity disorder (ADHD) was a welcome contribution to pediatricians' efforts to improve the care and outcomes of 6- to 12-year-old children with attention and behavior problems. As a chronic disorder that affects $4 \%$ to $12 \%$ of 6 - to 12 -year-old children 1 and results in very challenging personal, clinical, educational, and societal problems, ADHD is an appropriate focus for the efforts of the AAP and practicing pediatricians. There remain large discrepancies between pediatricians' practice patterns and the AAP guidelines. As many as 50\% of children with ADHD are unidentified and untreated [5]. 
ADHD prevalence seems to vary in different settings, such as in the general population versus in hospitals or in schools. In African countries, such as South Africa, Democratic Republic of Congo, or Ethiopia, the prevalence of ADHD has been reported to vary from 5.4\% to $8.7 \%$ among school children. However, in the general population, ADHD has been reported in $1.5 \%$ of children. And children with possible organic brain pathology have been reported to have a prevalence of ADHD of 45.5-100\% [6]. The prevalence of ADHD reported on other continents is variable. For instance, prevalence of ADHD in Saudi Arabian primary schools is reported to be as low as 2.7\%, while that in Iran is reported to be as high as 13\% [7,8]. In South America, the prevalence of ADHD in children is about 6\%, while in the USA it is as high as 16\% [9-11]. In Germany, ADHD has been reported with a prevalence of $4.8 \%$, while Ukraine has reported the highest incidence of ADHD to be 19\% [12]. Worldwide, the prevalence of ADHD is between 5.29\% and 7.1\% while in Nigeria study it was reported a prevalence of 3.2\% [13].

Zito et al [14] found that black youths were 2.5 times less likely to receive methylphenidate than were white youths. Bussing [15] reported that there are significantly greater barriers to ADHD treatment for girls, blacks, and poorer individuals; these barriers occur at multiple levels, including obtaining evaluations by parents, obtaining the diagnosis by the provider, and obtaining treatment. These studies confirm the importance of establishing appropriate mechanisms to ensure that children of both genders and all socioeconomic, racial, and ethnic groups receive appropriate assessment and treatment.

This study investigated the prevalence of ADHD in Arar city, the capital of the Northern province of the Kingdom of Saudi Arabia. Our hope is that this study will shed light on ADHD in Arar city to help parents of affected children cope with a diagnosis of ADHD.

\section{Study Objective:-}

The objective of this study is to determine the prevalence of ADHD among primary schools children of Arar city, the capital of the Northern province of the Kingdom of Saudi Arabia.

\section{Sample Size Estimation}

The minimum sample size required for this study was calculated using the following formula [16]

\section{$\mathbf{N}=\mathbf{Z}^{2} \mathbf{P}(\mathbf{1}-\mathbf{P}) / \mathbf{D}^{2}$}

where $\mathrm{Z}$ (i.e., the level of significance) $=1.96$; $\mathrm{P}=$ Prevalence of children with ADHD 16\% (maximal prevalence from a USA study); $\mathrm{D}=$ Tolerable error (0.05).

Using the formula above, we determined a minimum sample size of 206 patients. In anticipation of a $10 \%$ rate of attrition, the minimum sample size for our study is 270 .

The study conducted in four randomly selected primary schools in Arar city.Three hundred and five children and their teachers who met inclusion criteria filled the predesigned questionnaire which include the relevant questions for obtaining the needed socio-demographic data as age, sex, birth order between siblings, mother's and father's age, work and education, consanguinity between parents and average family income. 10 items of the Conners 10-item Abbreviated Teacher Rating Scale was translated and included in the questionnaire. Three hundreds of participants completed the questionnaire and were consecutively recruited into our cross sectional study between the 1st of March and the 30th of May, 2016.

A cutoff score of 15 on the Conners 10-item Abbreviated Teacher Rating Scale (ATRS) [17], based on a study from this laboratory, has been widely used by investigators for diagnosis of the syndrome known now as Attention Deficit Disorder with or without Hyperactivity. Children with scale higher than 15 considered to have the ADHD while children with scale less than 15 considered to be free.

\section{Ethical Consideration and Consent:-}

Ethical clearance for this study was sought from the Research and Ethical Committee of the Northern Border University of Arar, KSA and approved by Directorate of the Ministry of Education of the city. Informed consent was sought from parents/caregivers of potential subjects before enrolling them into the study. 


\section{Data Analysis:-}

Data was analyzed using the SPSS statistical package, version 16. The descriptive statistics were used for categorical and continuous variables, respectively.

\section{Results:-}

Three hundred children were included in this study, 180 children were male, 87 children were in the age group $<8$ year, $33 \%$ were between 8 and 10 -years-old and $81(27 \%)$ of children were in the age group 10 and 12-years-old. The birth order of $39 \%$ of the studied children was the first child between their siblings and only 30 of them were the last in order between siblings. 120 children had mothers who were between 30-40 year-old and 132 children had fathers in the same age group.

No consanguinity was reported between parents of most of the studied children (90\%). More than half of the studied children had their parents with university education. Mothers of $64 \%$ of the studied children were house wives and fathers of $41 \%$ of the studied children worked as teachers. Of the studied children, $45 \%$ had family income between 11000 and 15000 SR (Table 2).

Eighty children had ADHD with a percentage of $26.6 \%$ (Table 1).

Table 1:- Percentage distribution of ADHD in the studied children, Arar, KAS.

\begin{tabular}{|l|l|l|}
\hline ADHD & No. & $\%$ \\
\hline No & 220 & 73.3 \\
\hline Yes & 80 & 26.6 \\
\hline Total & 300 & 100.0 \\
\hline
\end{tabular}

Table 2:- Sociodemographic characteristics of the studied children, Arar, KSA.

\begin{tabular}{|c|c|c|}
\hline Age group & No $(n=305)$ & $\%$ \\
\hline$<8$ year & 87 & 29.0 \\
\hline $8-$ & 99 & 33.0 \\
\hline $10-$ & 81 & 27.0 \\
\hline $12+$ & 33 & 11.0 \\
\hline \multicolumn{3}{|l|}{ Sex } \\
\hline Female & 120 & 40.0 \\
\hline Male & 180 & 60.0 \\
\hline \multicolumn{3}{|c|}{ Child order between siblings } \\
\hline 1st one & 117 & 39.0 \\
\hline 2nd one & 60 & 20.0 \\
\hline 3rd one & 42 & 14.0 \\
\hline 4th one & 18 & 6.0 \\
\hline 5th one & 15 & 5.0 \\
\hline more than $5^{\text {th }}$ & 18 & 6.0 \\
\hline last one & 30 & 10.0 \\
\hline \multicolumn{3}{|c|}{ Age of the mother } \\
\hline$<20$ years & 3 & 1.0 \\
\hline$<30$ years & 96 & 32.0 \\
\hline $30-40$ years & 123 & 41.0 \\
\hline 40-50 Years & 78 & 26.0 \\
\hline \multicolumn{3}{|c|}{ Age of the father } \\
\hline $20-30$ years & 57 & 19.0 \\
\hline $30-40$ years & 132 & 44.0 \\
\hline 40-50 Years & 87 & 29.0 \\
\hline $50-60$ years & 21 & 7.0 \\
\hline$>60$ & 3 & 1.0 \\
\hline \multicolumn{3}{|c|}{ Consanguinity } \\
\hline 1st degree & 24 & 8.0 \\
\hline 2nd degree & 6 & 2.0 \\
\hline
\end{tabular}




\begin{tabular}{|l|l|l|}
\hline No & 270 & 90.0 \\
\hline Mother's education & & \\
\hline Not educated & 75 & 25.0 \\
\hline 1ry school & 24 & 8.0 \\
\hline Intermediate school & 6 & 2.0 \\
\hline 2ry school & 27 & 9.0 \\
\hline University & 168 & 56.0 \\
\hline Father's education & & \\
\hline Not educated & 3 & 1.0 \\
\hline 1ry school & 18 & 6.0 \\
\hline 2ry school & 105 & 35.0 \\
\hline University or more & 174 & 58.0 \\
\hline Mother's work & & \\
\hline House wife & 192 & 64.0 \\
\hline Nurse & 27 & 9.0 \\
\hline Teacher & 81 & 27.0 \\
\hline Father's work & & \\
\hline Not work & 3 & 1.0 \\
\hline Nurse & 48 & 16.0 \\
\hline Retired & 15 & 5.0 \\
\hline Soldier & 93 & 31.0 \\
\hline Teacher & 123 & 41.0 \\
\hline Work in private sector & 18 & 6.0 \\
\hline Family income range & & \\
\hline$<8000$ SR* & 24 & 8.0 \\
\hline $8000-10000$ SR & 111 & 37.0 \\
\hline $11000-15000$ SR & 135 & 45.0 \\
\hline$>15000$ SR & 30 & 10.0 \\
\hline SR Saw Rya & & \\
\hline
\end{tabular}

SR* Saudi Ryal

\section{Discussion:-}

This study conducted to show the prevalence of ADHD in Arar city, the capital of the Northern province of the Kingdom of Saudi Arabia, hoping to shed light on ADHD in Arar city to help parents of affected children cope with a diagnosis of ADHD and seek medical advise.

In this study we determined that the prevalence of ADHD was 26.3\%. our figure is far more than the prevalence of ADHD in other studies Saudi Arabian primary schools is which reported to be as low as 2.7\%, while that in Iran is reported to be as high as $13 \%$ [7,8]. In South America, the prevalence of ADHD in children is about 6\%, while in the USA it is as high as $16 \%$ [9-11].

In contrast to Nigeria study which found the prevalence of ADHD was 3.2\% [1114] and other reviews of the literature have reported highly variable prevalence rates for ADHD worldwide, Ukraine has reported the highest incidence of ADHD to be 19\% [12]. The prevalence of ADHD is between 5.29\% and 7.1\% [13] to a high of almost $20 \%$ among school-age American children [18]. This prevalence was determined from studies conducted in a school environment. Although the causes of the variability in ADHD prevalence worldwide are unknown, geographic and demographic factors have been implicated [19]. The prevalence of ADHD obtained in our study is similar to that of studies conducted in schools, where prevalence of ADHD has been reported from $1.7 \%$ to $17.8 \%$ [20,21].

The opinion that geographic location may influence the epidemiology of ADHD and attention deficit hyperactivity symptoms persists despite findings to the contrary in a few studies that culture and geographic location may have little to no influence on the epidemiology of ADHD worldwide [22]. 
It has also been argued by other experts that the variability in ADHD/HD prevalence estimates may be best explained by the use of different case definitions. They argue that the actual prevalence across geographic sites should not vary when case definitions are identical [23,24].

\section{Conclusion and Recommendation:-}

We conclude that the prevalence of ADHD in our setting was similar to that in other parts of the world, and there is need for additional studies in this region. This is because ADHD is one of the emerging mental health problems and a neglected health issue in Arar, KSA.

\section{Acknowledgment:-}

The success and final outcome of this research paper required assistance from many people and I am extremely fortunate to have got this all along the completion of this work. My thanks go to Mohammed Ali Alhowaish $\left(6^{\text {th }}\right.$ yearFaculty of medicine, northern border university)and Abdalla Mohamed Bakr Ali for their cooperation in different steps of the research.

\section{References:-}

1. American Academy of Pediatrics, "Clinical practice guideline: diagnosis and evaluation of the child with attention-deficit/hyperactivity disorder," Pediatrics, vol. 105, no. 5, pp. 1158-1170, 2000. View at Publisher · View at Google Scholar · View at Scopus

2. E. G. Willcutt, "The prevalence of DSM-IV attention-deficit/hyperactivity disorder: a meta-analytic review," Neurotherapeutics, vol. 9, no. 3, pp. 490-499, 2012. View at Publisher - View at Google Scholar · View at Scopus

3. American Academy of Pediatrics. Clinical practice guideline: diagnosis

4. and evaluation of the child with attention-deficit/hyperactivity disorder (AC002). Pediatrics. 2000;105:1158-1170.

5. American Academy of Pediatrics. Clinical practice guideline: treatment of the school-aged child with attentiondeficit/hyperactivity disorder. Pediatrics. 2001;108:1033-1044

6. National Institutes of Health. Diagnosis and treatment of attention deficit hyperactivity disorder. NIH Consens Statement. 1998;16(2):1-37

7. M. O. Bakare, "Attention deficit hyperactivity symptoms and disorder (ADHD) among African children: a review of epidemiology and co-morbidities," African Journal of Psychiatry, vol. 15, no. 5, pp. 358-361, 2012. View at Google Scholar • View at Scopus

8. M. M. J. Alqahtani, "Attention-deficit hyperactive disorder in school-aged children in Saudi Arabia,"European Journal of Pediatrics, vol. 169, no. 9, pp. 1113-1117, 2010. View at Publisher · View at Google Scholar · View at Scopus

9. A. Talaei, N. Mokhber, E. Abdollahian, M. R. F. Bordbar, and E. Salari, "Attention deficit/hyperactivity disorder: a survey on prevalence rate among male subjects in elementary school (7 to 9 years old) in Iran," Journal of Attention Disorders, vol. 13, no. 4, pp. 386-390, 2010. View at Publisher · View at Google Scholar . View at Scopus

10. L. A. Rohde, J. Biederman, E. A. Busnello et al., "ADHD in a school sample of Brazilian adolescents: A study of prevalence, comorbid conditions, and impairments," Journal of the American Academy of Child and Adolescent Psychiatry, vol. 38, no. 6, pp. 716-722, 1999. View at Publisher · View at Google Scholar · View at Scopus

11. "Childhood ADHD rate increases $22 \%$ in the U.S. Can the TM technique help," 2014, http://www.tm.org/blog/research/adhd-transcendental-meditation/.

12. K. D. Gadow, E. E. Nolan, L. Litcher et al., "Comparison of attention-deficit/hyperactivity disorder symptom subtypes in Ukrainian schoolchildren," Journal of the American Academy of Child and Adolescent Psychiatry, vol. 39, no. 12, pp. 1520-1527, 2000. View at Publisher · View at Google Scholar · View at Scopus

13. "Epidemiology of attention deficit hyperactive disorder," 2014, http://en.wikipedia.org/wiki/Epidemiology_of_attention_deficit_hyperactive_disorder.

14. Ullmann RK, Sleator EK, Sprague RL. A change of mind: the Conners abbreviated rating scales reconsidered. J Abnorm Child Psychol. 1985 Dec;13(4):553-65.

15. Zito JM, Safer DJ, dosReis S, Riddle MA. Racial disparity in psychotropic medications prescribed for youths with Medicaid insurance in Maryland. J Am Acad Child Adolesc Psychiatry. 1998;37:179-184 
16. Bussing R. Barriers to help-seeking and treatment for ADHD. Presented at: American Psychiatric Association 53rd Institute on Psychiatric Services; October $10-14$, 2001; Orlando, FL. Available at: www. hypsos.ch/articles/effttt.htm. Accessed November 15, 2004

17. M. O. Araoye, Research Methodology with Statistics for Health and Social Sciences, Nathadox, Ilorin, Nigeria, 1st edition, 2004.

18. J. M. Chinawa, O. I. Odetunde, Herbert A. Obu, A. T. Chinawa, Muideen O. Bakare, and F. A. Ujunwa. Attention Deficit Hyperactivity Disorder: A Neglected Issue in the Developing World. Behavioural Neurology Volume 2014 (2014), Article ID 694764, 6 pages

19. S. V. Faraone, J. Sergeant, C. Gillberg, and J. Biederman, "The worldwide prevalence of ADHD: is it an American condition?" World Psychiatry, vol. 2, pp. 104-113, 2003. View at Google Scholar.

20. K. D. Gadow, E. E. Nolan, L. Litcher et al., "Comparison of attention-deficit/hyperactivity disorder symptom subtypes in Ukrainian schoolchildren," Journal of the American Academy of Child and Adolescent Psychiatry, vol. 39, no. 12, pp. 1520-1527, 2000. View at Publisher · View at Google Scholar · View at Scopus

21. M. D. Rappley, "Attention deficit-hyperactivity disorder," The New England Journal of Medicine, vol. 352, no. 2, pp. 165-173, 2005. View at Publisher · View at Google Scholar • View at Scopus

22. "Childhood ADHD rate increases $22 \%$ in the U.S. Can the TM technique help," 2014, http://www.tm.org/blog/research/adhd-transcendental-meditation/.

23. "Attention deficit hyperactivity symptoms and disorder (ADHD) among African children: a review of epidemiology and co-morbidities," http://www.ajol.info/index.php/ajpsy/article/viewFile/81823/71966.

24. J. M. Swanson, J. A. Sergeant, E. Taylor, E. J. S. Sonuga-Barke, P. S. Jensen, and D. P. Cantwell, "Attentiondeficit hyperactivity disorder and hyperkinetic disorder," The Lancet, vol. 351, no. 9100, pp. 429-433, 1998. View at Publisher • View at Google Scholar · View at Scopus

25. M. Gaub and C. L. Carlson, "Gender differences in ADHD: a meta-analysis and critical review," Journal of the American Academy of Child and Adolescent Psychiatry, vol. 36, no. 8, pp. 1036-1045, 1997. View at Publisher · View at Google Scholar · View at Scopus 